\title{
Evidence for decline in the incidence of cystic fibrosis: a 35-year observational study in Brittany, France
}

\author{
Virginie Scotet ${ }^{1,2,3^{*}}$, Ingrid Duguépéroux ${ }^{1,2,3,4}$, Philippe Saliou ${ }^{1,2,3,4}$, Gilles Rault ${ }^{5}$, Michel Roussey ${ }^{6,7}$,
} Marie-Pierre Audrézet ${ }^{1,2,3,4}$ and Claude Férec ${ }^{1,2,3,4}$

\begin{abstract}
Background: Cystic fibrosis (CF) is an autosomal recessive disorder whose incidence has long been estimated as 1/2500 live births in Caucasians. Expanding implementation of newborn screening (NBS) programs now allows a better monitoring of the disease incidence, what is essential to make reliable predictions for disease management. This study assessed time trends in the birth incidence of CF over a long period (35 years: 1975-2009) in an area where CF is frequent (Brittany, France) and where NBS has been implemented for more than 20 years.

Methods: This study enrolled CF patients born in Brittany between January $1^{\text {st }} 1975$ and December $31^{\text {st }} 2009$ ( $\mathrm{n}=$ 483). Time trends in incidence were examined using Poisson regression and mainly expressed using the average percent change (APC).

Results: The average number of patients born each year declined from 18.6 in the late 1970's (period 1975-79) to 11.6 nowadays (period 2005-09). The corresponding incidence rates dropped from 1/1983 to 1/3268, which represented a decline close to $40 \%$ between these two periods (APC $=-39.3 \%, 95 \% \mathrm{Cl}=-55.8 \%$ to $-16.7 \%, \mathrm{p}=$ 0.0020). A clear breakpoint in incidence rate was observed at the end of the 1980's ( $p<0.0001)$. However, the incidence rate has remained quite stable since that time (annual APC $=-1.0 \%, 95 \% \mathrm{Cl}=-3.0 \%$ to $1.1 \%, \mathrm{p}=0.3516$ ).

Conclusions: This study provides an accurate picture of the evolution of the incidence of a genetic disease over a long period and highlights how it is influenced by the health policies implemented. We observed a 40\% drop in incidence in our area which seems consecutive to the availability of prenatal diagnosis.
\end{abstract}

Keywords: Cystic fibrosis, Incidence, Time trends, Newborn screening, Pregnancy ultrasound examination

\section{Background}

Cystic fibrosis (CF; OMIM\#219700) is an autosomal recessive disorder due to mutations in the CFTR (Cystic Fibrosis Transmembrane conductance Regulator) gene, which was cloned in 1989 [1]. Newborn screening (NBS) for $\mathrm{CF}$, which has progressively been implemented worldwide over the past years, now allows better monitoring of the birth incidence of CF, which appears lower than in the past. Long estimated as 4.0/10,000 (i.e. 1/2500) live births in Caucasians [2], the average birth incidence rate is now 2.9/10,000 (i.e. 1/3500) in Europe [3,4].

\footnotetext{
* Correspondence: virginie.scotet@inserm.fr

'Inserm, U1078, Brest, F-29200, France

Full list of author information is available at the end of the article
}

Time trends in the birth incidence of CF have been investigated in several studies, but the magnitude of the reported changes varies according to the areas and to the length of the period under study [5-8]. The trends observed result from a complex mixture of phenomena and have been ascribed to various health policies (as prenatal diagnosis, family testing [9], population-based carrier screening [10-12]) and/or to demographic factors (as reduction of family size, increase of population mixing with consecutive decline of endogamy and inbreeding [8]).

Time trends in the birth incidence therefore depend on the health policies implemented in the studied population, but also on the characteristics of the population (i.e. carrier rate, cultural attitudes toward prenatal
Ciomed Central

() 2012 Scotet et al; licensee BioMed Central Ltd. This is an Open Access article distributed under the terms of the Creative Commons Attribution License (http://creativecommons.org/licenses/by/2.0), which permits unrestricted use, distribution, and reproduction in any medium, provided the original work is properly cited. 
diagnosis and pregnancy termination, birth rate, etc). Monitoring of CF incidence is therefore essential to be able to make reliable predictions for disease management in the future.

In this study, we examined time trends in the incidence of CF over a long period (the longest ever studied to date: 35 years, 1975-2009) in an area where CF is frequent (Brittany, western France), where NBS has been implemented for a long time (since 1989) but where carrier screening (both preconceptional screening and prenatal screening) is not underway.

\section{Methods}

\section{Study population}

This study enrolled CF patients born in Brittany (western France) between January $1^{\text {st }} 1975$ and December $31^{\text {st }}$ 2009. Confined at the western end of Europe, Brittany is a region of three million inhabitants where the incidence of CF is among the highest in the world [13] and where an NBS program has been under way since 1989 [14]. This particular situation led us to set up a registry of molecular epidemiology of CF in this area, in order to analyze temporal trends in incidence and survival [13].

Brittany has a relatively homogeneous population, which mainly results from historical waves of migrations of Celtic people. The geographical structure of this area (peninsula) coupled with the use, for many centuries, of a Celtic language (the Breton) have contributed to the isolation of its population. This resulted in low populations' mixings and high levels of endogamy and inbreeding.

\section{Data sources}

The patients included in the present study were extracted from this registry, which also gathers newborn screening and prenatal diagnosis data. As previously described [13], patients born before the set up of NBS were retrieved through active enquiries and a combination of data sources (with capture-recapture studies). Patients born since the implementation of NBS were easily collected by consulting data from the French organization in charge of this program (A.F.D.P.H.E.) as well as data from the genetics laboratories of our area.

In order to ensure data homogeneity, the same inclusion criteria were used throughout. Patients with an equivocal diagnosis that could have been detected through NBS were excluded from the analysis (i.e. newborns screened with ambiguous sweat test results and/ or CFTR mutations not clearly associated with CF, as for example those carrying the R117H: $\mathrm{n}=19$ ) [15-17]. All patients born during the study period were enrolled, including siblings as well as false-negative cases missed by our NBS program.

\section{Statistical analysis}

Statistical analysis was performed using SAS software (version 9.2-SAS Institute, Cary, NC, USA). The significance level was set at $p \leq 5 \%$ for all analyses.

\section{Birth incidence rate calculation}

The birth incidence rate of CF (with its 95\% confidence interval-95\% CI) was determined for the whole study period, by 5 -year periods and by year. The incidence rate of a given year was calculated by dividing the number of $\mathrm{CF}$ children born over that year by:

1) Prior to the implementation of NBS: the number of live births that occurred in Brittany over that year (data provided by the French Institute of Statistics and Economic Studies).

2) After the implementation of NBS: the number of screening tests performed in Brittany over that year (data provided by the organization in charge of the NBS program). It is important to note that the refusal rate for this test is extremely low in our area $(<0.01 \%)$.

\section{Time trends analysis}

Time trends in the incidence rates were examined using Poisson regression, which enables to model count or rate data. This approach, which derives from generalized linear models [18], is classically used to analyze time trends in incidence of cancers or of chronic diseases.

The analyses were conducted by considering the whole study period, but also 5 -year periods as well as other periods of interest (defined by the time of implementation of prenatal diagnosis or newborn screening). For all analyses, the oldest period was taken as reference.

The changes observed in the incidence rates were expressed by two parameters:

1) the odds-ratio (OR) with its $95 \% \mathrm{CI}$. The OR corresponds to the exponential of the $\beta$ coefficient that estimates the effect of time. It indicates how much the incidence rate observed over a period has decreased in comparison with the reference period.

2) the average percent change (APC) with its $95 \%$ CI. This parameter is derived from the formula $([\exp (\beta)-1]$ *100) and represents the percentage of variation observed in the incidence rates between the periods of interest ([Incidence Period-Incidence $_{\text {Reference period] }}$ /Incidence Reference period). When time is coded as the year of birth, the APC represents the annual average percent change in the incidence rate.

All the models were fitted using the "Proc genmod" procedure in the SAS software. A constant rate of change was assumed over the period concerned (log-linearity assumption) and the presence of under/over dispersion was checked by introducing the term "scale = pearson" in the models. 


\section{Adjusted incidence rate calculation}

Prenatal diagnosis of CF was developed in the early 1980's $[19,20]$. Beyond the parents of CF child(ren), prenatal diagnosis is offered to the 1-in-4 risk couples identified through family testing, but also, since the early 1990's, to the 1-in-4 risk couples identified following the in utero detection of a sonographic sign suggestive of CF (echogenic bowel). If the fetus is found to be CFaffected, genetic counseling is offered to the couple and the possibility of therapeutic termination is made available.

As we have knowledge of the number of pregnancy terminations performed yearly after a positive prenatal diagnosis (made by molecular biology) in our area, we were also able to calculate an adjusted incidence rate (by adding these data to the calculations) and therefore to assess the impact of prenatal diagnosis on the incidence rate. We also examined in detail the contexts in which the 1-in-4 risk was discovered (i.e. the contexts in which the PD was done), and assessed the impact of each of these contexts on the incidence rate.

This research protocol was approved by the Comité Consultatif sur le Traitement de l'Information en Matière de Recherche dans le domaine de la Santé and by the Commission Nationale d'Informatique et des Libertés.

\section{Results}

\section{Birth incidence rate and its time trends}

A total of 483 CF children born in Brittany between January $1^{\text {st }} 1975$ and December $31^{\text {st }} 2009$ were recorded. Half of them ( $n=243,50.3 \%)$ were born since the implementation of the NBS program in 1989. The CFTR genotype could be fully determined in $96.5 \%$ of the patients $(n=466)$ and $56.0 \%$ of them $(n=261)$ were homozygous for the main F508del (p.Phe508del) mutation. These data led to a global CF birth incidence rate of $3.8 / 10,000(95 \% \mathrm{CI}=3.4 / 10,000$ to $4.2 / 10,000)$ in Brittany over the study period (i.e. 1/2637).

Figure 1 shows the evolution of the annual birth incidence rate of CF over the 35-year period. Despite yearto-year variations, Poisson regression analysis revealed a significant decrease in the incidence rate over the whole study period $(\mathrm{p}<0.0001)$. The annual APC was $-1.8 \%$ (95\% CI $=-2.6 \%$ to $-1.0 \%)$, meaning that the incidence rate decreased on average by $1.8 \%$ each year.

The analysis performed by 5 -year periods (Tables 1 and 2) indicated that the incidence rate dropped from $5.0 / 10,000$ (i.e. $1 / 1983$ ) in the late 1970 's to $3.1 / 10,000$ (i.e. 1/3268). The average number of CF children born each year over these two periods decreased from 18.6 to 11.6.

Detailed examination of the data revealed a clear breakpoint in the incidence rate at the end of the 1980's. As illustrated in Table 2, the incidence rates of the last four 5-year periods appeared quite similar, and were significantly lower than those of the first three periods. These rates were respectively $1.53,1.57,1.62$ and 1.65 times lower than that of the oldest period (197579). This can also be observed in Figure 2, which shows the evolution of the birth incidence rate by 5 -year period.

The most significant change was observed when the year 1990 was considered as the cut-off time. The incidence rate decreased from 4.6/10,000 (i.e. 1/2171) before this year to $3.2 / 10,000$ (i.e. 1/3158) afterwards (corresponding to a decline of $31.3 \%, \mathrm{p}<0.0001)$. One can also note that the proportion of sibships with several CF children significantly dropped at the same time (from 9.3\% over the period $1975-1989$ to $3.2 \%$ over the period 1990-2009, $\mathrm{p}=0.0094)$.

The incidence rate has remained quite constant since the early 1990's, since when no significant decline has been observed (annual APC $=-1.0 \%, 95 \% \mathrm{CI}=-3.0 \%$ to $1.1 \%, \mathrm{p}=0.3516)$.

\section{Adjusted incidence rate}

Finally, we calculated an adjusted incidence rate by taking into account the pregnancy terminations performed after a positive prenatal diagnosis of CF in our area (Table 3).

Since prenatal diagnosis of CF was done by molecular techniques (i.e. 1986), 105 terminations were performed in such a context among couples living in Brittany, i.e. a mean of four per year. If all these affected pregnancies had resulted in the birth of a CF child, the overall CF incidence rate over the period 1986-2009 would have been $4.6 / 10,000$ (i.e. $1 / 2169$ ) instead of 3.4/10,000 (i.e. $1 / 2946)$, i.e. $35.8 \%$ higher.

As shown in Table 4, most of the 105 terminations (60.0\%) were done in the parents of previous CF child (ren), 23.8\% were done in couples whose 1-in-4 risk was identified following the ultrasound detection of a sign suggestive of CF during pregnancy, and $16.2 \%$ were done in 1-in-4 risk couples identified through family testing. Table 4 also shows that, in our area, the impact of the sonographic detection of a sign evocative of CF during pregnancy appeared higher than the impact of family testing.

\section{Discussion}

This study deciphers how the incidence of CF has evolved over a long time (the longest ever studied to date: 35 years) in an area where CF is frequent (Brittany, France) and where population-based carrier screeningknown to significantly decrease the incidence [12]-is not underway. It also highlights how the incidence is influenced by the health policies implemented. 


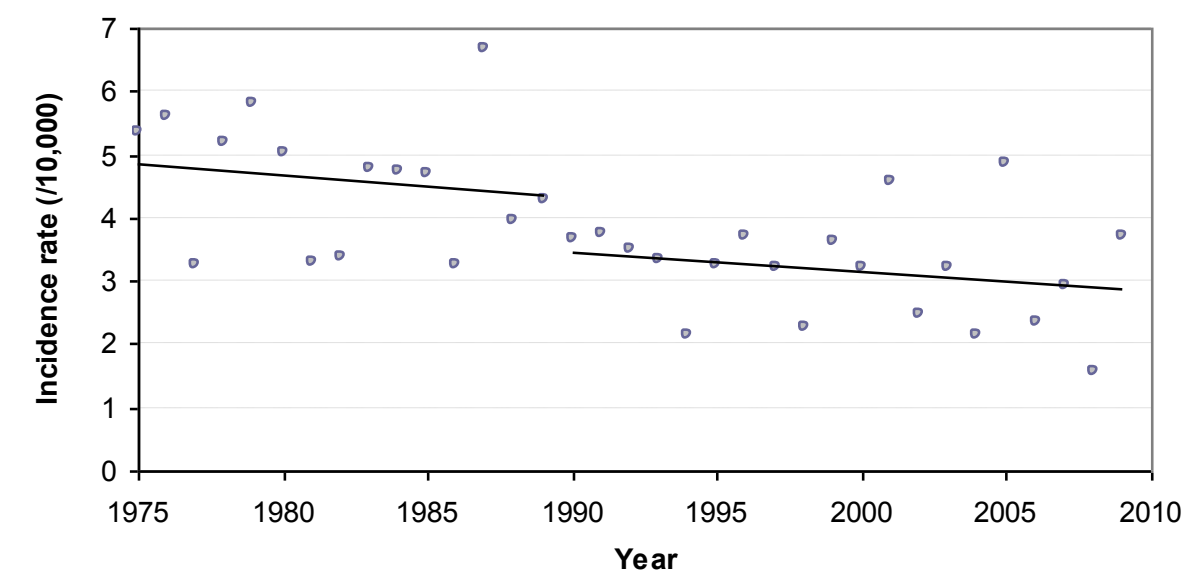

Figure 1 Evolution of the annual birth incidence rate of cystic fibrosis in Brittany over the period 1975-2009. As statistical analysis revealed that the most significant change in incidence rate was observed when the year 1990 was considered as the cut-off time, we plotted the trendlines independently for the periods 1975-1989 and 1990-2009.

This study reveals a clear fall in the incidence rate, which dropped by $40 \%$ between the period 1975-79 and 2005-09. The observed breakpoint coincides with the more common use of prenatal diagnosis since the end of the 1980's. This test has been increasingly used notably by couples identified to be at risk following NBS, which was implemented in our area in 1989. This study also highlights the importance of ultrasound monitoring performed during pregnancy, which may identify new 1in-4 risk couples following detection of echogenic bowel.

We have been able to measure accurately the impact of prenatal diagnosis in our area as we have an exhaustive collection of its data. By including pregnancy terminations in the calculations, we have shown that the incidence rate would have been $35.8 \%$ higher than that observed to date. The impact of this test appears particularly high in Brittany. Indeed, despite the progress accomplished over the past decades in the field of CF, most 1 -in-4 risk couples in our area request prenatal diagnosis and $95 \%$ choose not to continue the pregnancy if the fetus is affected [21].

However, the impact of prenatal diagnosis on incidence rate remains relatively limited in areas where population-based carrier screening is not implemented.
Indeed, this test can only be offered to 1 -in-4 risk couples related to a CF patient or to a carrier child identified through NBS. Therefore, most carrier couples are at risk without knowing it, and can give birth to a $\mathrm{CF}$ child. In our area, one individual in 29 is a healthy carrier. Only the implementation of carrier screening may significantly reduce the incidence, as recently shown in an Italian area [12]. Population-based carrier screening consists in offering genetic testing to all the couples planning a pregnancy in a given population. Aware of their high risk, the couples found to have a 1-in-4 risk may opt for prenatal diagnosis and may choose to terminate the pregnancy if the fetus is CF-affected. Such a program is not underway in our area, and this is probably why the incidence has remained stable since the early 1990's.

The present study provides an accurate picture of the evolution of the incidence of CF on the scale of an entire population over a long period. It relies on exhaustive collection of data in a large region whose geographical situation (peninsula) means that the data are well centralized and easier to collect. A few biases may have affected our study. Since 1989, an NBS program has been implemented in our area, which ensures quasi-

Table 1 Birth incidence rates of cystic fibrosis in Brittany by 5-year period (period 1975-2009).

\begin{tabular}{ccccc}
\hline Period & No. patients & No. births & Incidence $(\mathbf{9 5 \%} \mathrm{Cl})(\mathbf{1 / x x x})$ & Incidence $(\mathbf{9 5 \%} \mathrm{Cl})(\mathbf{1 0 , 0 0 0})$ \\
\hline $\mathbf{1 9 7 5 - 1 9 7 9}$ & 93 & 184407 & $\mathbf{1 / 1 9 8 3}(1 / 2413 ; 1 / 1629)$ & $\mathbf{5 . 0}(4.1 ; 6.1)$ \\
$\mathbf{1 9 8 0 - 1 9 8 4}$ & 80 & 189746 & $\mathbf{1 / 2 3 7 2}(1 / 3880 ; 1 / 1450)$ & $\mathbf{4 . 2}(2.6 ; 6.9)$ \\
$\mathbf{1 9 8 5 - 1 9 8 9}$ & 82 & 179446 & $\mathbf{1 / 2 1 8 8}(1 / 3573 ; 1 / 1340)$ & $\mathbf{4 . 6}(2.8 ; 7.4)$ \\
$\mathbf{1 9 9 0 - 1 9 9 4}$ & 56 & 169926 & $\mathbf{1 / 3 0 3 4}(1 / 5123 ; 1 / 1797)$ & $\mathbf{3 . 3}(2.0 ; 5.5)$ \\
$\mathbf{1 9 9 5 - 1 9 9 9}$ & 56 & 174412 & $\mathbf{1 / 3 1 1 5}(1 / 5258 ; 1 / 1845)$ & $\mathbf{3 . 2}(1.9 ; 5.4)$ \\
$\mathbf{2 0 0 0 - 2 0 0 4}$ & 58 & 186054 & $\mathbf{1 / 3 2 0 8}(1 / 5396 ; 1 / 1907)$ & $\mathbf{3 . 1}(1.9 ; 5.2)$ \\
$\mathbf{2 0 0 5 - 2 0 0 9}$ & 58 & 189563 & $\mathbf{1 / 3 2 6 8}(1 / 5498 ; 1 / 1943)$ & $\mathbf{3 . 1}(1.8 ; 5.1)$ \\
\hline
\end{tabular}


Table 2 Results of the time trend analysis: odds-ratio (OR) and average percent change (APC) associated with each 5year period (period 1975-2009).

\begin{tabular}{|c|c|c|c|c|c|}
\hline Period & Incidence $(1 / x x x x)$ & Incidence $(/ 10,000)$ & OR $(95 \% \mathrm{Cl}) \mathrm{e}^{\beta}$ & $\operatorname{APC}(95 \% \mathrm{Cl})\left(\mathrm{e}^{\beta}-1\right)^{*} 100$ & $p$ \\
\hline 1975-1979 & $1 / 1983$ & 5.0 & ref. & ref. & - \\
\hline $1980-1984$ & $1 / 2372$ & 4.2 & $\mathbf{0 . 8 4}(0.63 ; 1.12)$ & $-16.4 \%(-37.4 \% ; 11.6 \%)$ & 0.2243 \\
\hline 1985-1989 & $1 / 2188$ & 4.6 & $0.91(0.68 ; 1.21)$ & $-9.4 \%(-32.0 \% ; 20.7 \%)$ & 0.5007 \\
\hline 1990-1994 & $1 / 3034$ & 3.3 & $\mathbf{0 . 6 5}(0.47 ; 0.90)$ & $\mathbf{- 3 4 . 7 \%}(-52.6 \% ;-10.0 \%)$ & 0.0093 \\
\hline 1995-1999 & $1 / 3115$ & 3.2 & $\mathbf{0 . 6 4}(0.46 ; 0.88)$ & $-\mathbf{3 6 . 3} \%(-53.8 \% ;-12.3 \%)$ & 0.0058 \\
\hline 2000-2004 & $1 / 3208$ & 3.1 & $\mathbf{0 . 6 2}(0.45 ; 0.85)$ & $\mathbf{- 3 8 . 2 \%}(-55.0 \% ;-15.1 \%)$ & 0.0029 \\
\hline 2005-2009 & $1 / 3268$ & 3.1 & $\mathbf{0 . 6 1}(0.44 ; 0.83)$ & $-39.3 \%(-55.8 \% ;-16.7 \%)$ & 0.0020 \\
\hline
\end{tabular}

exhaustive registration of new cases at birth. False-negative cases are always a possibility, but the cases reported so far (which are few in number in the last decade) have been included in the calculations $(n=10)$. Newborn screening may also diagnose atypical cases that do not meet all the criteria for CF [22,23]. To overcome this problem, which may alter time trends, equivocal diagnoses were excluded from the analysis [15]. Another pitfall that could affect our findings is under-reporting and/or under-diagnosis of cases predating the setting of NBS. The active combination of data sources and the use of capture-recapture studies may have limited this phenomenon. Anyway, in such a situation, the incidence rate would have been still greater in that period, and the observed drop still higher.

Several studies have analyzed time trends in the incidence of CF. While most have reported a decline, some have not observed any temporal change [24]. The findings are however difficult to compare because the studies have been conducted over various periods and in areas that have not implemented similar public health policies and that have different attitudes towards prenatal diagnosis.

The oldest studies were conducted from registry data (prone to under-diagnosis and/or under-reporting), mainly in countries that did not practice NBS. In Canada, time trends were analyzed over the period 1971-2000 and a linear decline was noted since 1988, which coincided with the increased use of family testing and prenatal diagnosis services [6]. In the Netherlands, the incidence rate observed over the period 1974-1997 $(2.1 / 10,000$ i.e. $1 / 4780)$ was found to be significantly lower than that estimated over a previous period (19611965: $2.9 / 10,000$ i.e. $1 / 3600)$ [7,25]. In the UK, a constant decline in incidence rate was also observed over a 26-year period (1968-1994) from data of the UK Registry [5].

More recent studies have analyzed time trends in the incidence rate since the implementation of NBS [8]. The region of East Anglia (UK), where NBS has been in place since 1981, experienced a constant decline over the period 1981-1990. In the State of Victoria (Australia), a $17 \%$ reduction in the birth incidence of CF was seen following the introduction of NBS in 1989 [26]. The incidence dropped from 3.96/10,000 (i.e. 1/2525) live births over the period $1979-1988$ to $3.28 / 10,000$ (i.e. $1 / 3050$ ) over the period 1989-2006. This was attributed to the uptake of prenatal diagnosis, especially in families identified by NBS. Brittany appears to be similar in various respects, such as the date of implementation of an

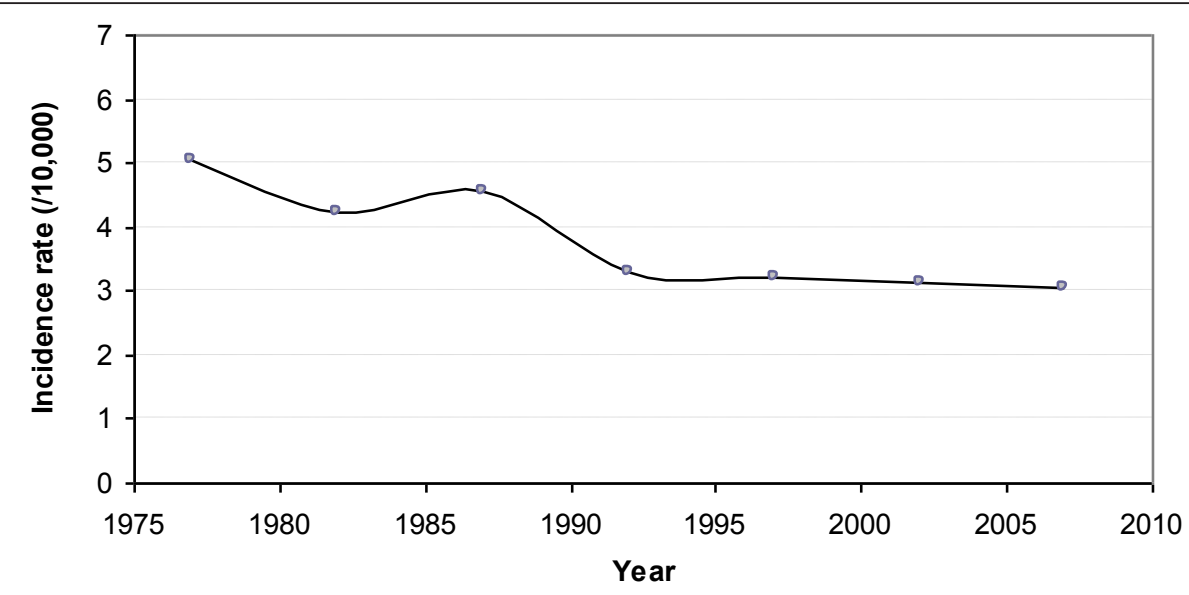

Figure 2 Evolution of the birth incidence rate of cystic fibrosis in Brittany by 5-year period, over the period 1975-2009. 
Table 3 Impact of prenatal diagnosis on the incidence rate of cystic fibrosis in Brittany (period 1986-2009).

\begin{tabular}{lcccc}
\hline & Pregnancy terminations & \multicolumn{2}{c}{ Incidence rate } & \multicolumn{2}{c}{ Variation in incidence } \\
& No. & $\mathbf{( 1 / x x x x )}$ & $(/ \mathbf{1 0 , 0 0 0 )}$ & (\%) \\
\hline Birth incidence rate of CF & & $1 / 2946$ & 3.4 & \\
Adjusted birth incidence rate of CF & 105 & $1 / 2169$ & 4.6 & $\mathbf{3 5 . 8 \%}$ \\
\hline
\end{tabular}

Table 4 Distribution of pregnancy terminations performed in Brittany according to the context of prenatal diagnosis of cystic fibrosis, and assessment of the impact of each strategy on the incidence rate (period 1986-2009).

\begin{tabular}{|c|c|c|c|c|c|}
\hline \multirow[t]{2}{*}{ Context of prenatal diagnosis } & \multicolumn{2}{|c|}{$\begin{array}{l}\text { Pregnancy } \\
\text { terminations }\end{array}$} & \multicolumn{2}{|c|}{ Incidence rate } & \multirow{2}{*}{$\begin{array}{c}\text { Variation in incidence } \\
(\%)\end{array}$} \\
\hline & No. & Freq. & $(1 / x x x x)$ & $(/ 10,000)$ & \\
\hline Parents of a CF child & 63 & $60.0 \%$ & $1 / 2425$ & 4.1 & $21.5 \%$ \\
\hline 1-in-4 risk couples identified through family testing & 17 & $16.2 \%$ & $1 / 2784$ & 3.6 & $5.8 \%$ \\
\hline 1-in-4 risk couples identified following ultrasound examination of pregnancy & 25 & $23.8 \%$ & $1 / 2714$ & 3.7 & $8.5 \%$ \\
\hline Total & 105 & $100.0 \%$ & $1 / 2169$ & 4.6 & $35.8 \%$ \\
\hline
\end{tabular}

NBS program, the attitudes towards request of pregnancy terminations, etc. Nevertheless, the decline we observed in our area is rather higher and may, in part, result from the greater uptake of family testing and the efficiency of routine ultrasound monitoring of pregnancy, which is, in our country, supported by our health care system.

In the US, a significant decline has been observed in the States of Wisconsin and of Massachusetts since the implementation of NBS (in 1994 and 1999, respectively) $[11,27]$, whereas no temporal trend has been noted in the State of Colorado, which has been screening newborns for longer (since 1982) [24]. In Massachusetts there has also been reported a change in the composition of the screened cohort (notably a decrease in the proportion of the main F508del/F508del genotype) which coincides with the implementation of carrier screening [11]. As in Colorado, we did not find such a change in our population over time.

A greater decline has recently been found in an area of northern Italy (Veneto/Trentino Alto Adige) over the period 1993-2007, particularly in the region where carrier screening is underway (mean annual decrease of $0.24 / 10,000)$ [12]. The authors have also noted a significant correlation between the increase in the number of 1 -in- 4 risk couples identified and the decline in incidence.

\section{Conclusion}

This study highlights that the time trends observed in the incidence rate depend on the health policies implemented in the studied population (i.e. newborn screening, prenatal diagnosis, carrier screening, etc), but also on the characteristics of the population (i.e. carrier rate, cultural attitudes toward prenatal diagnosis and pregnancy termination, birth rate, etc).
We show, in this study, that the birth incidence of CF has dropped in our area following the implementation of prenatal diagnosis. However, the birth incidence appears now quite stable. The sole strategy that could strongly modify the current incidence of CF would be the routine carrier screening of couples planning a pregnancy. Implementation of such a program has proven successful in reducing the incidence of $C F$ in the State of Massachusetts [11] or in Northern Italy [12], but also the incidence of other diseases, such as thalassemia [28].

Improvement in survival of CF patients as well as in assisted reproduction techniques should help alter the disease dynamics in the future. It is therefore essential to keep on monitoring the incidence to be able to make reliable disease predictions. It is also crucial to maintain and strengthen efforts to improve clinical management and patients' quality of life.

List of abbreviations

APC: Average percent change; CF: Cystic fibrosis; CFTR: Cystic Fibrosis Transmembrane conductance Regulator; NBS: Newborn screening; OR: Oddsratio; 95\% Cl: 95\% confidence interval.

\section{Acknowledgements}

This study was supported by a grant from the French Ministry of Health (PHRC 2007). The authors thank all the physicians involved in the management of CF in Brittany, as well as the Association Française de Dépistage et de Prévention des Handicaps de I'Enfant (A.F.D.P.H.E.) for supplying data.

\section{Author details}

${ }^{1}$ Inserm, U1078, Brest, F-29200, France. ${ }^{2}$ Univ Brest, Brest, F-29200, France. ${ }^{3}$ Etablissement Français du Sang-Bretagne, Brest, F-29200, France. ${ }^{4} \mathrm{CHRU}$ Brest, Hôp. Morvan, Laboratoire de Génétique Moléculaire, Brest, F-29200, France. ${ }^{5}$ Centre de ressources et de compétences de la mucoviscidose, Roscoff, F-29680, France. ${ }^{6}$ Centre de ressources et de compétences de la mucoviscidose, Rennes, F-35000, France. ${ }^{7}$ Association Française pour le Dépistage et la Prévention des Handicaps de l'Enfant (AFDPHE), Paris, F75000, France. 


\section{Authors' contributions}

VS and CF conceived and designed the study. VS carried out the statistical analysis and drafted the manuscript. ID managed data collection and participated with PS to data analysis and interpretation. MPA, GR and MR contributed to data collection. All authors revised the manuscript critically for important intellectual content and approved the final version.

\section{Competing interests}

The authors declare that they have no competing interests.

Received: 20 October 2011 Accepted: 1 March 2012

Published: 1 March 2012

\section{References}

1. Riordan JR, Rommens JM, Kerem B, Alon N, Rozmahel R, Grzelczak Z, Zielenski J, Lok S, Plavsic N, Chou JL, Drumm ML, lannuzzi MC, Collins FS, Tsui LC: Identification of the cystic fibrosis gene: cloning and characterization of complementary DNA. Science 1989, 245:1066-73.

2. Welsh MJ, Ramsey BW, Accurso FJ, Cutting GR: Cystic fibrosis. In The Metabolic and Molecular Basis of Inherited Disease.. 8 edition. Edited by: Scriver CR, Beaudet AL, Sly WS, Valle D, Childs B, Vogelstein B. New York: McGraw Hill; 2001:5121-88.

3. Southern KW, Munck A, Pollitt R, Travert G, Zanolla L, Dankert-Roelse J, Castellani C: A survey of newborn screening for cystic fibrosis in Europe. J Cyst Fibros 2007, 6:57-65.

4. Salvatore D, Buzzetti $R$, Baldo E, Forneris MP, Lucidi V, Manunza D, Marinelli I, Messore B, Neri AS, Raia V, Furnari ML, Mastella G: An overview of international literature from cystic fibrosis registries. Part 3. Disease incidence, genotype/phenotype correlation, microbiology, pregnancy, clinical complications, lung transplantation, and miscellanea. J Cyst Fibros 2011, 10:71-85.

5. Dodge JA, Morison S, Lewis PA, Coles EC, Geddes DM, Russell G, Littlewood JM, Scott MT: Incidence, population, and survival of cystic fibrosis in the UK, 1968-95. Arch Dis Child 1997, 77:493-6.

6. Dupuis A, Hamilton D, Cole DE, Corey M: Cystic fibrosis birth rates in Canada: a decreasing trend since the onset of genetic testing. J Pediatr 2005, 147:312-5.

7. Slieker MG, Uiterwaal $C S$, Sinaasappel $M$, Heijerman $H G$, van der $L$, van der Ent CK: Birth prevalence and survival in cystic fibrosis: a national cohort study in the Netherlands. Chest 2005, 128:2309-15.

8. Green MR, Weaver LT, Heeley AF, Nicholson K, Kuzemko JA, Barton DE, McMahon R, Payne SJ, Austin S, Yates JRW, Davis JA: Cystic fibrosis identified by neonatal screening: incidence, genotype, and early natural history. Arch Dis Child 1993, 68:464-7.

9. Super M, Schwarz MJ, Malone G, Roberts T, Haworth A, Dermody G: Active cascade testing for carriers of cystic fibrosis gene. BMJ 1994, 308:1462-7.

10. Mennie ME, Gilfillan A, Compton M, Curtis L, Liston WA, Pullen I, Whyte DA, Brock DJH: Prenatal screening for cystic fibrosis. Lancet 1992, 340:214-6.

11. Hale JE, Parad RB, Comeau AM: Newborn screening showing decreasing incidence of cystic fibrosis. N Engl J Med 2008, 358:973-4.

12. Castellani C, Picci L, Tamanini A, Girardi P, Rizzotti P, Assael BM: Association between carrier screening and incidence of cystic fibrosis. JAMA 2009, 302:2573-9.

13. Scotet V, Gillet D, Duguépéroux I, Audrézet MP, Bellis G, Garnier B, Roussey M, Rault G, Parent P, De Braekeleer M, Férec C, Réseau mucoviscidose Bretagne et Pays-de-Loire: Spatial and temporal distribution of cystic fibrosis and of its mutations in Brittany, France: a retrospective study from 1960. Hum Genet 2002, 111:247-54.

14. Scotet V, De Braekeleer M, Roussey M, Rault G, Parent P, Dagorne M, Journel H, Lemoigne A, Codet JP, Catheline M, David V, Chaventré A, Duguépéroux I, Verlingue C, Quéré I, Mercier B, Audrézet MP, Férec C: Neonatal screening for cystic fibrosis in Brittany, France: assessment of 10 years' experience and impact on prenatal diagnosis. Lancet 2000, 356:789-94.

15. Mayell SJ, Munck A, Craig JV, Sermet I, Brownlee KG, Schwarz MJ, Castellani C, Southern KW: A European consensus for the evaluation and management of infants with an equivocal diagnosis following newborn screening for cystic fibrosis. J Cyst Fibros 2009, 8:71-8.

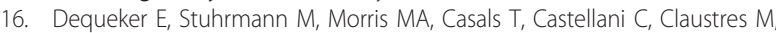
Cuppens H, Des GM, Férec C, Macek M, Pignatti PF, Scheffer H, Schwartz M, Witt M, Schwarz M, Girodon E: Best practice guidelines for molecular genetic diagnosis of cystic fibrosis and CFTR-related disorders-Updated European recommendations. Eur J Hum Genet 2009, 17:51-65.

17. Castellani C, Cuppens H, Macek M Jr, Cassiman JJ, Kerem E, Durie P, Tullis E, Assael BM, Bombieri C, Brown A, Casals T, Claustres M, Cutting GR, Dequeker E, Dodge J, Doull I, Farrell P, Férec C, Girodon E, Johannesson M, Kerem B, Knowles M, Munck A, Pignatti PF, Radojkovic D, Rizzotti P, Schwarz M, Stuhrmann M, Tzetis M, Zielenski J, Elborn JS: Consensus on the use and interpretation of cystic fibrosis mutation analysis in clinical practice. J Cyst Fibros 2008, 7:179-96.

18. Dobson AJ, Barnett AG: An introduction to generalized linear models. 3 edition. Chapman and Hall/CRC; 2008.

19. Brock DJ: Amniotic fluid alkaline phosphatase isoenzymes in early prenatal diagnosis of cystic fibrosis. Lancet 1983, 2:941-3.

20. McIntosh I, Raeburn JA, Curtis A, Brock DJ: First-trimester prenatal diagnosis of cystic fibrosis by direct gene probing. Lancet 1989, 2:972-3.

21. Scotet V, Duguépéroux I, Audrézet MP, Blayau M, Boisseau P, Journel H, Parent $P$, Férec C: Prenatal diagnosis of cystic fibrosis: the 18-year experience of Brittany (western France). Prenat Diagn 2008, 28:197-202

22. Rosenstein BJ, Cutting GR: The diagnosis of cystic fibrosis: a consensus statement. Cystic Fibrosis Foundation Consensus Panel. J Pediatr 1998 132:589-95.

23. Farrell PM, Rosenstein BJ, White TB, Accurso FJ, Castellani C, Cutting GR, Durie PR, Legrys VA, Massie J, Parad RB, Rock MJ, Campbell PW III: Guidelines for diagnosis of cystic fibrosis in newborns through older adults: Cystic Fibrosis Foundation consensus report. J Pediatr 2008, 153: S4-S14.

24. Sontag MK, Wagener JS, Accurso FJ, Sagel SD: Consistent incidence of cystic fibrosis in a long-term newborn screen population [abstract]. Pediat Pulmonol 2008, 43:272, (A203).

25. Ten Kate LP: Cystic fibrosis in the Netherlands. Int J Epidemiol 1977, 6:23-34.

26. Massie J, Curnow L, Gaffney L, Carlin J, Francis I: Declining prevalence of cystic fibrosis since the introduction of newborn screening. Arch Dis Child 2010, 95:531-3.

27. Stachiw-Hietpas D, Hoffman G, Nugent M, Schneck K, Kennedy-Parker K, Roch MJ, Farrell PM, Simpson P, Levy H: Wisconsin newborn screening program results suggest a decreasing incidence of $\mathrm{CF}$ in the white nonhispanic population [abstract]. Pediat Pulmonol 2010, 45:390, (A474).

28. Cao A, Rosatelli MC, Monni G, Galanello R: Screening for thalassemia: a model of success. Obstet Gynecol Clin North Am 2002, 29:305-28.

doi:10.1186/1750-1172-7-14

Cite this article as: Scotet et al: Evidence for decline in the incidence of cystic fibrosis: a 35-year observational study in Brittany, France. Orphanet Journal of Rare Diseases 2012 7:14.

\section{Submit your next manuscript to BioMed Central and take full advantage of:}

- Convenient online submission

- Thorough peer review

- No space constraints or color figure charges

- Immediate publication on acceptance

- Inclusion in PubMed, CAS, Scopus and Google Scholar

- Research which is freely available for redistribution

Submit your manuscript at www.biomedcentral.com/submit
C Biomed Central 